
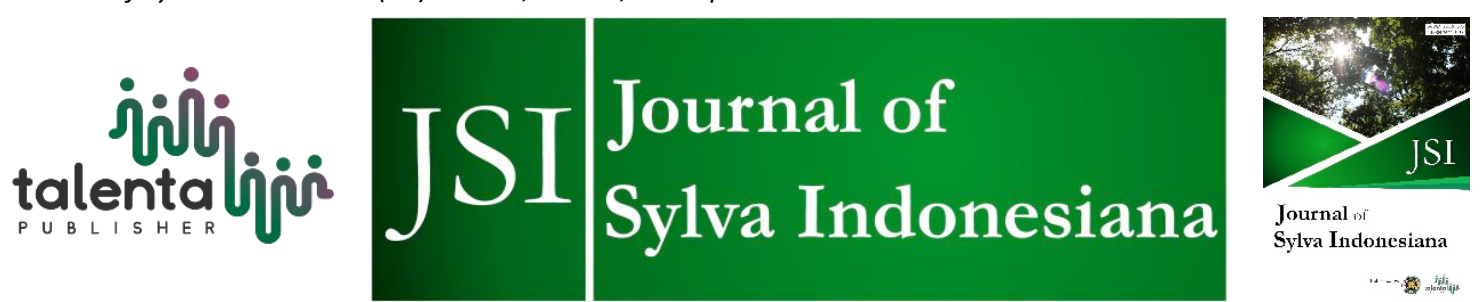

\title{
Assessment of Five-Year Vegetation Cover Changes to Support Green Open Spaces Monitoring in Surakarta, Central Java, Indonesia
}

\author{
Moehar Maraghiy Harahap ${ }^{1,2}$, Erny Poedjirahajoe ${ }^{3}$, Sigit Heru Murti \\ Budi Santosa ${ }^{4}$, and Mariah Ulfa ${ }^{1,2}$ \\ ${ }^{I}$ Department of Forest Conservation, Faculty of Forestry, Universitas Sumatera Utara, North Sumatera, \\ Indonesia \\ ${ }^{2} J A T I$ - Sumatran Forestry Analysis Study Center, North Sumatra, Indonesia \\ ${ }^{3}$ Department of Forest Conservation, Faculty of Forestry, Gadjah Mada University, Yogyakarta, \\ Indonesia \\ ${ }^{4}$ Department of Cartography and Remote Sensing, Faculty of Geography, Gadjah Mada University, \\ Yogyakarta, Indonesia
}

\begin{abstract}
Surakarta City's population is growing every year, putting pressure on the land and vegetation. Surakarta City has a population of 500,173 people in 2010. The population of this city is growing every year, driving an increase in the demand for land and living facilities. This study aims to analyze the availability of vegetated land as urban green space, and calculate the 5-year (2010-2015) vegetation cover changes. The methods used visual interpretation and on-screen digitization of the image Landsat 7 ETM+ satellite in 2010 and Landsat 8 OLI satellite image in 2015. The results show that the availability of vegetated land as urban green space in Surakarta City is lower than that mandated in Law Number 26 of 2007 concerning Spatial Planning. Vegetation cover decreased from 2010 to 2015 in Surakarta City, covering an area of 117.7 ha (2.6\% of the city area) or an average of 23.5 ha $(0.5 \%)$ per year. Research on the availability of green open spaces on a regular basis is expected to be part of the process of monitoring and evaluating urban development and as input for local governments in the decision-making process.
\end{abstract}

Keyword: City Development, Population, Satellite Image Interpretation, Vegetation

Received 15 July 2021 | Revised 3 August 2021 | Accepted 4 August 2021

\section{Introduction}

The increasing human population always causes pressure on land and the environment [1]. Land conversion particularly for will be directed affecting the vegetated land [2]. In developing cities, the demand for housing, industrial expansion, and the building of living facilities tends to increase in line with population growth. Changes in land cover that occur continuously make the

\footnotetext{
*Corresponding author at: Department of Forest Conservation, Faculty of Forestry, Universitas Sumatera Utara, Jl. Tri Dharma Ujung No.1, Medan 20155, North Sumatra, Indonesia

E-mail address:mhr_mrghy@usu.ac.id

Published by Talenta Publisher

p-ISSN: 2622-5093 e-ISSN: 2622-5158 DOI: 10.32734/jsi.v4i02.6496

Journal Homepage: http://jsi.usu.ac.id
} 
new environmental problems. The increase in surface air temperature in urban areas is one of them [3]. This is the result of vegetation's ability to produce a suitable microclimate. As a complement to environmental degradation, conservation efforts to increase or sustain existing vegetation are necessary [4]. On the remaining open land or shrubbery, one effort that can be undertaken is to provide urban green space [4].

Urban areas defined as places having non-agricultural main activities, including the role of the area as a location for urban settlements, government service centralization and distribution, social services, and economic activities [5]. Surakarta is known as one of the cultural cities in Indonesia [6]-[8]. Surakarta is included in one of the ten cities with the largest population density, reaching 500,173 people in 2010 [7]. Surakarta's population grew from 512,226 people in 2005 to 512,226 people in 2015. In comparison to the past several years, the population increase from 2010 to 2015 was the greatest. During this time, the average annual population growth was 2.40 percent, or roughly 2,400 people [8]. For comparison, in the period $2006-$ 2010 population growth in this city was only $0.49 \%$ per year.

The city of Surakarta's growing population is pushing greater pressure on vegetated areas, which serve as urban green space. Surakarta has a shrub-covered land cover of 3,434.85 hectares in 1997 . Then it decreased sharply to $1,717.02$ hectares in 2007. Land cover in the form of settlement, on the other hand, is increasing from year to year [9]. Due to the rapid rate of urbanization with various purposes and limited land availability, chances for land conversion from vegetated to non-vegetated or settlement land occur. This results in a conflict between human needs and environmental sustainability [1]. Settlements, urban infrastructure buildings, and roadways are among the land uses that have increased every year [1]-[2].

The focus of this research is to examine the availability of vegetated land as urban green space (UGS) and evaluate the five-year perio (2010-2015) vegetation cover changes in Surakarta City. Research conducted on the availability of urban green space is expected to be part of the process of monitoring and evaluating urban development, as well as a source of knowledge for local governments in the decision-making.

\section{Methods}

This research was conducted in Surakarta City, Central Java. The materials used in this study were Landsat 7 ETM+ images recorded in July 2010 and Landsat 8 OLI images recorded in June 2015 with the location of path 119 row 065 (source: https://www.usgs.gov) and the Earth Map of Surakarta. The tools used include a computer and Arc GIS 10.2 software to process spatial data, a Global Positioning System (GPS) to determine the coordinates of checking positions in the field (groundcheck) and a camera to document research activities. 


\subsection{Data analysis}

\section{A. Land cover analysis}

The initial stage in this procedure is to correct the geometric and radiometric errors. Geometric correction aims to restore the satellite image's original position on the earth's surface by adjusting the shift in its coordinates. To improve the visual quality (texture, colour, and form) of satellite imagery, radiometric correction is used to reduce atmospheric disturbances such as clouds and fog in satellite photography. The pixel value that does not match the actual reflectance value of an object can be increased using radiometric correction [10]-[11].

The purpose of the Landsat image analysis is to create a land cover map of the area. Landsat image management needs to match both spatial and descriptive information from the images [12]. Visual interpretation and on-screen digitalization were employed as categorization methods in this study. One of the advantages of this method is that it can distinguish land cover based on pixel appearances that seem to be difficult when using automatic classification [10]. A field survey (ground check) is conducted to determine the truth and fix any discrepancies between the type of land cover represented on the map and actual field conditions [1].

Land cover types are divided into eight categories. The land cover classes are divided to aid visual interpretation of vegetation cover in Surakarta City over a 5-year period and to accommodate the spatial resolution of Landsat satellite images, which is $30 \mathrm{~m} \times 30 \mathrm{~m}$ per pixel. The presence or absence of the dominating vegetation as observed through visual interpretation of satellite data and the results of field surveys are the criterion for the distribution of land cover.

In the field, the type of land cover described as urban green space is one that is dominated by tree vegetation. Non-UGS land cover, on the other hand, is a form of land use that is dominated by building or field agriculture with limited tree vegetation. As a result, it is clear how many vegetated areas exist in Surakarta City that serve as urban green space.

\section{B. Land cover change analysis}

Analysis of land cover changes that occurred in the period 2010-2015 in Surakarta City was carried out using Arc GIS 10.2. Changes that occur within a span of 5 years are identified through change detection techniques [13]. Change detection works with the principle of overlaying each land cover map being studied (2010 and 2015). The end result of this process is a change in the shape and size of each land cover according to its newest function [10]. These changes will provide information on what processes have occurred during the period of observation. 


\section{Results and Discussion}

In Surakarta City, the results of the interpretation of vegetated land cover categories based on Landsat images in 2015 are provided in Table 1. Table 1 shows that the area of urban green space in Surakarta was 778.8 ha (17.7\%) in 2015, which is lower than non-vegetation cover (settlements and rice fields). River borders, which occupy 382.0 ha, city parks and sports fields, which cover 121.9 ha, and mixed gardens, which cover 61.4 ha, are the most common types of urban green space in Surakarta City.

Table 1 Types of land cover and types of urban green space (UGS) in 2015 in Surakarta

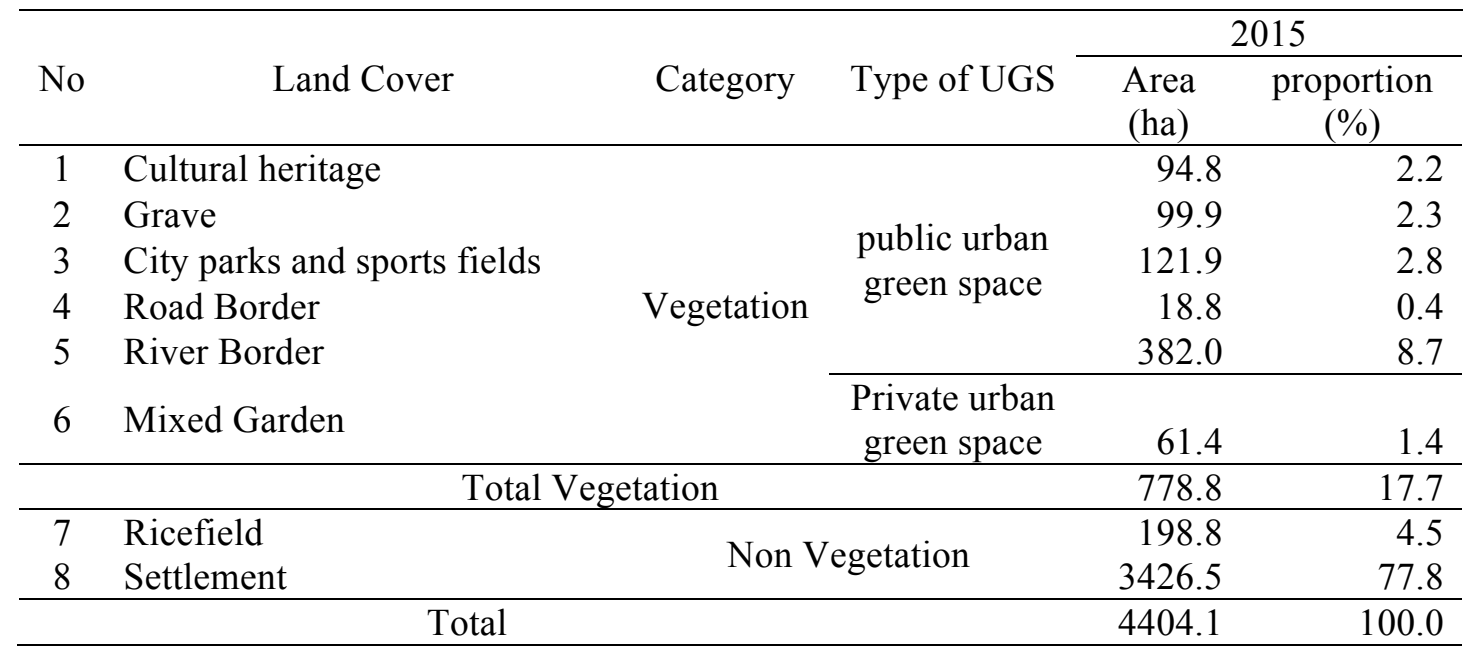

Settlement is the most dominant form of land use in Surakarta City with an area of 3,426.5 ha or covering $77.8 \%$ of the city area. Yards of houses and buildings that have vegetation are visually interpreted as residential areas. This interpretation is based on image visualization and the spectral resolution of Landsat images which only reach $30 \mathrm{~m} \times 30 \mathrm{~m}$. Constructed land dominates the surrounding region, which exceeds the presence of vegetation in the yard or in high-rise buildings. Because the vegetation in residential and construction areas is usually residual or young, it cannot cover a big enough area. Because it is located in a densely populated residential area, residual vegetation in residential areas and buildings is also changeable and loss. As a consequence, this remaining and young vegetation is considered as a residential area.

Table 1 also shows that the number of public urban green spaces in Surakarta City is $16.4 \%$, while private green space is only $1.4 \%$. This is not in accordance with the minimum proportion of urban green space in an administrative area, which is $20 \%$ public UGS and $10 \%$ private UGS [14]. The Surakarta City Government needs to find a solution to increase the proportion of the public UGS area in order to achieve the ideal area. One effort that can be done is to provide urban green space on the remaining open land or shrubs [4]. When creating an urban green space, native tree species must be considered. This native species, will attracted wildlife especially birds to visit and reproduce [15]. 
Maintenance and addition of urban green space needs to be done to achieve the ecological needs of urban areas. The target of these activities is residential areas that are densely populated and become centers of social and economic activities for the community, such as in the center of Surakarta City. Road borders have the smallest area compared to other UGS types with a proportion of only about $0.4 \%$ (18.8 ha). Maintenance and expansion of road borders will increase the availability of UGS in this city as well as a form of mitigating the phenomenon of urban temperature rise [9]. UGS is able to provide various environmental services that cannot be replaced by other forms of land use. One of the environmental services that can be provided by urban green space is to absorb $\mathrm{CO} 2$ emissions from the transportation sector [16].

The 5 years observation shows that there has been a land use change in Surakarta City from 2010 to 2015. Mixed gardens, rice fields, and river borders all have seen changes in land use and a reduction in area. Cultural heritage, graves, and road boundaries are the categories of land cover that haven't changed in five years. Changes in vegetation cover from 2010 to 2015 in Surakarta City are presented in Table 2.

Table 2 Land cover change from 2010 to 2015 in Surakarta City

\begin{tabular}{|c|c|c|c|c|c|c|c|c|}
\hline \multirow{2}{*}{$\begin{array}{c}\mathrm{N} \\
\mathrm{o}\end{array}$} & \multirow{2}{*}{ Land Cover } & \multirow{2}{*}{ Category } & \multicolumn{2}{|c|}{2010} & \multicolumn{2}{|c|}{2015} & \multicolumn{2}{|c|}{$\begin{array}{c}\text { Perubahan } 2010 \text { - } \\
2015\end{array}$} \\
\hline & & & $\begin{array}{l}\text { Area } \\
\text { (ha) }\end{array}$ & $\begin{array}{c}\text { Proportion } \\
(\%)\end{array}$ & $\begin{array}{l}\text { Area } \\
\text { (ha) }\end{array}$ & $\begin{array}{c}\text { Proportion } \\
(\%)\end{array}$ & $\begin{array}{l}\text { Area } \\
\text { (ha) }\end{array}$ & $\begin{array}{c}\text { Proportion } \\
(\%)\end{array}$ \\
\hline 1 & Cultural heritage & \multirow{6}{*}{ Vegetasi } & 94.8 & 2.2 & 94.8 & 2.2 & 0.0 & 0.0 \\
\hline 2 & Grave & & 99.9 & 2.3 & 99.9 & 2.3 & 0.0 & 0.0 \\
\hline 3 & $\begin{array}{l}\text { City parks and sports } \\
\text { fields }\end{array}$ & & 114.5 & 2.6 & 121.9 & 2.8 & 7.4 & 0.2 \\
\hline 4 & Mixed Garden & & 180.6 & 4.1 & 61.4 & 1.4 & -119.2 & -2.7 \\
\hline 5 & Road Border & & 18.8 & 0.4 & 18.8 & 0.4 & 0.0 & 0.0 \\
\hline \multirow[t]{2}{*}{6} & River Border & & 387.9 & 8.8 & 382.0 & 8.7 & -5.9 & -0.1 \\
\hline & Total Vegetation & & 896.5 & 20.4 & 778.8 & 17.8 & & \\
\hline 7 & Ricefield & Non & 219.6 & 5.0 & 198.8 & 4.5 & -20.8 & -0.5 \\
\hline \multirow[t]{2}{*}{8} & Settlement & $\begin{array}{l}\text { Vegeta- } \\
\text { tion }\end{array}$ & 3288.0 & 74.7 & 3426.5 & 77.8 & 138.5 & 3.1 \\
\hline & Total & & 4404.1 & 100.0 & 4404.1 & 100.0 & & \\
\hline
\end{tabular}

Table 2 shows that the type of land cover that increased in area over a five-year period was residential, which increased by 138.5 ha, and city parks and sports fields, which increased by 7.4 ha. Residential areas are increasing in line with previous research conducted by [9]. The type of paddy field cover in Surakarta City was decreasing every year, inversely equal to settlements, city parks, and sports fields [17]. Figure 1 illustrates the land cover map for the year 2010. 


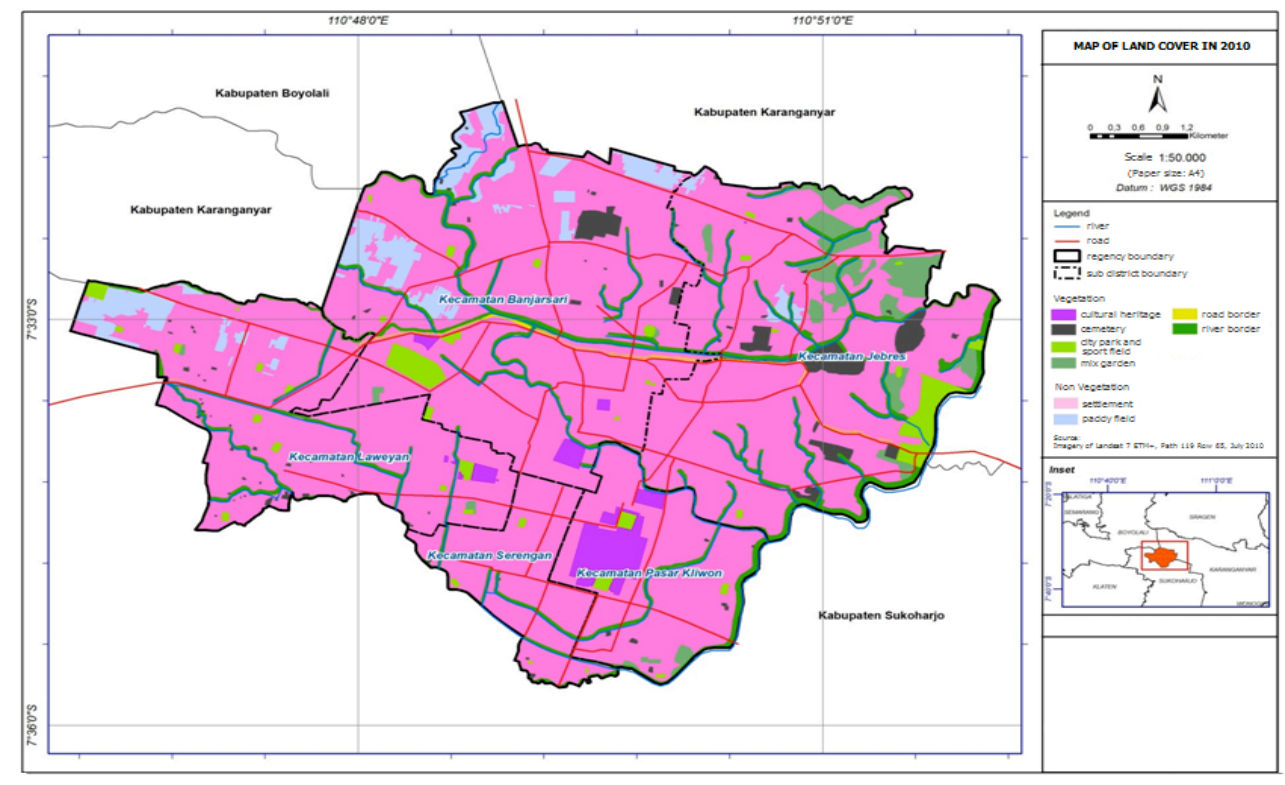

Figure 1 Land cover map of Surakarta City in 2010

Based on Figure 1, it is known that settlement is the most dominant type of land cover in the city of Surakarta in 2010 with a proportion of more than $70 \%$ of the city area. The majority of land in Surakarta is indeed designated for settlements, schools, factories and trade centers [6][8],[18]. This policy will almost certainly put impact on the environment's quality in the future [18]. Over the last five years, the residential area on the 2015 land cover map (Figure 2) has increased.

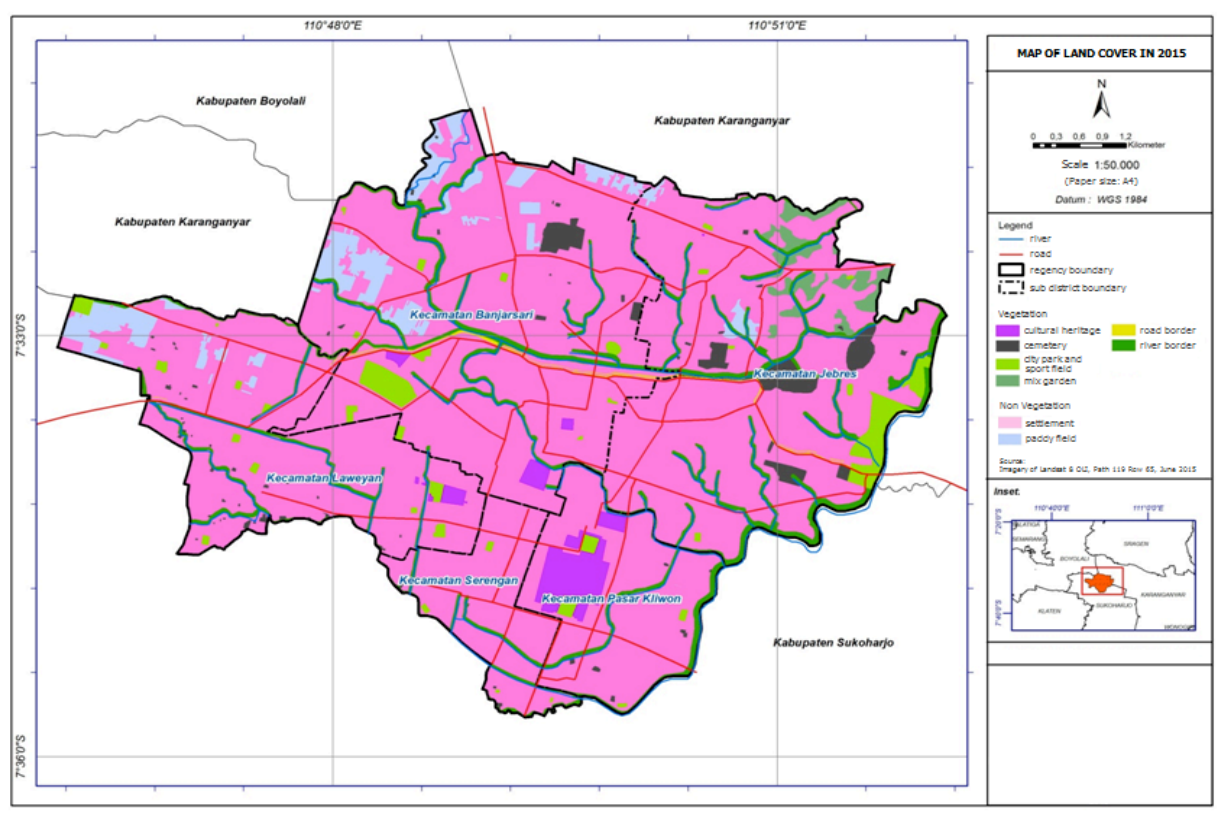

Figure 2 Map of land cover of Surakarta City in 2015

Mixed gardens and paddy fields experienced changes in land use (Figure 2) and decreased by 119.2 ha and 20.8 ha in 2015. Both are land covers that are most susceptible to changes in land 
use compared to other land covers. Mixed gardens and rice fields are property rights so that they can be easily converted into other forms of land use in accordance with the wishes and needs of the community [2],[9]. Changes in land use in the development process are difficult to avoid [2], especially on private land (Figure 3).

Private UGS in the form of mixed gardens tends to decrease from year to year, according to the results of Landsat satellite image interpretation and field surveys. The development of settlements or new housing areas on the periphery of the city has resulted in declining in the private area of UGS. Increased activity and urbanization also result in land use change [3]. Land use change is also driven by human activities and population density. Humans will be interested in changing land in terms of generating income to meet their needs [19].
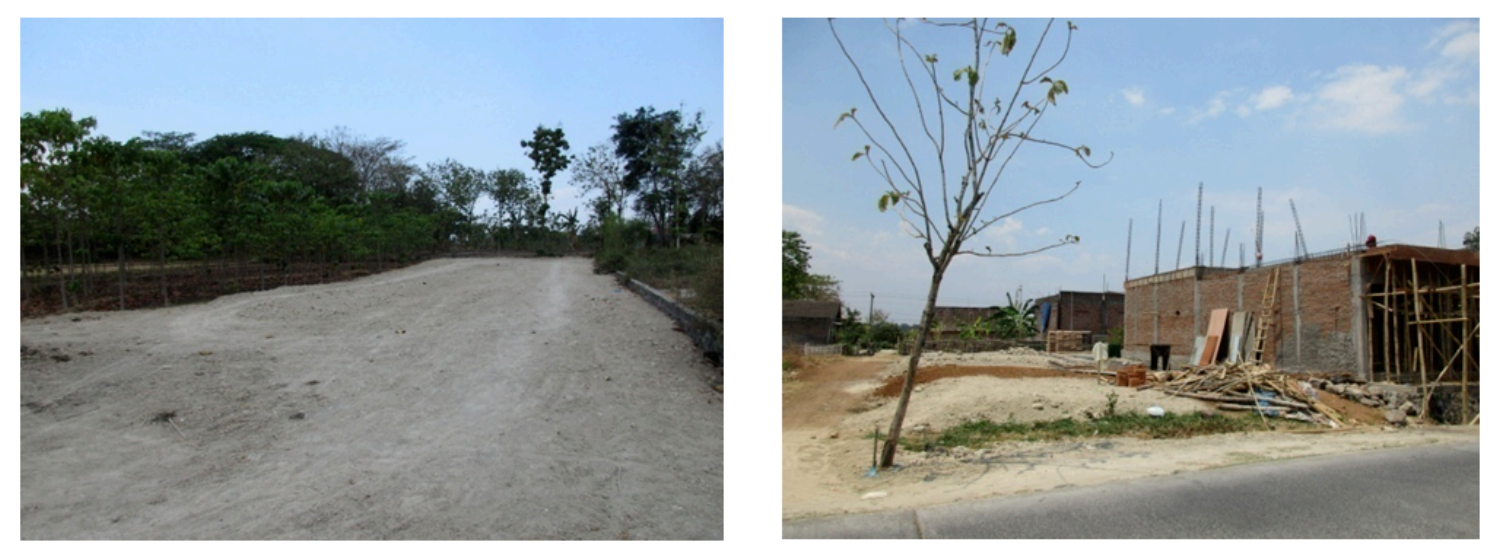

Figure 3 The conversion of mixed garden land and rice fields into settlement

The information in Table 2 indicates that the need for land as a place to live in Surakarta tends to increase from year to year. This is in line with the trend of data on the population of Surakarta City which continues to increase every year [6]-[8]. Figure 4 shows the population growth trend over a ten-year period (2006-2015).

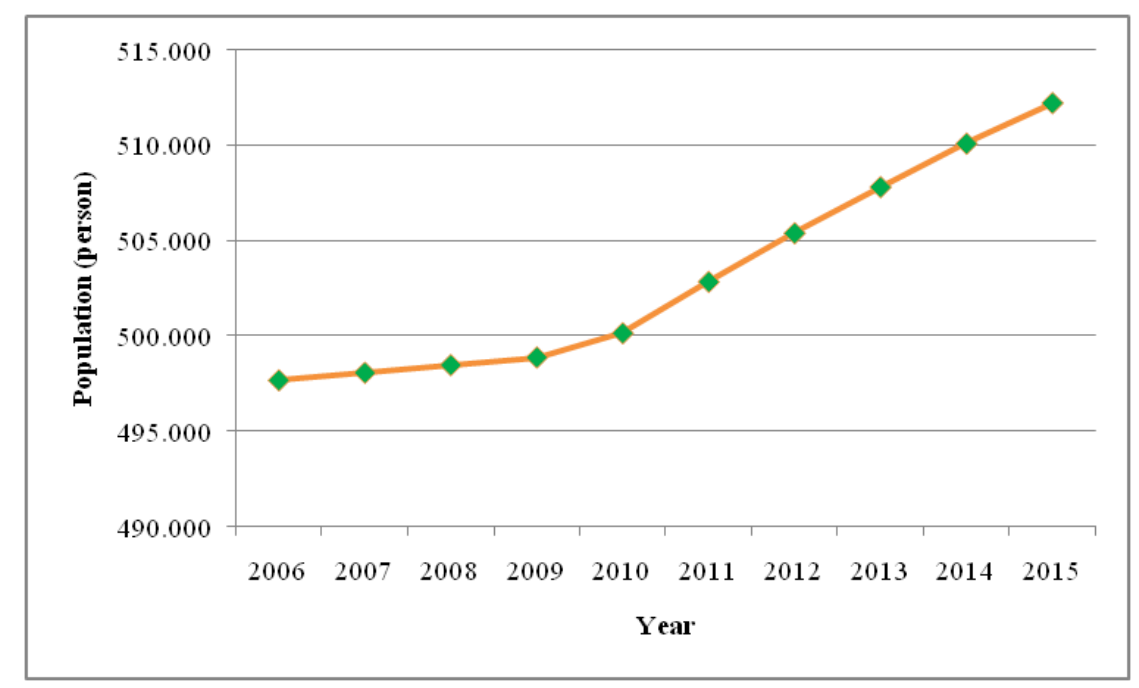

Figure 4 Population trends of Surakarta City from 2006 to 2015 
Figure 3 shows trend in population in Surakarta city. From 2010 and 2015, there was a fairly significant increase in population. In contrast to the previous five years, this period had seen the highest increase in population. During 2010 and 2015, the annual average population growth was $2.40 \%$, or about 2,400 people [8]. If referring to the period 2006-2010 population growth in this city is only $0.49 \%$ per year.

The rapid growth of Surakarta's population puts pressure on vegetated land conversion for fulfill basic human needs such as housing, industry, and urban facilities. The increase in population has been considered as one of the main drivers of land use change in several previous studies [15],[20]. The increase of population followed by the increasing of need for food and other resources land resources [2].

\section{Conclusion}

Surakarta City's availability of vegetated land as urban green space is lower than that required by Law No. 26 of 2007. In Surakarta City, vegetation cover declined from 2010 to 2015, covering 117.7 hectare ( $2.6 \%$ of the city area) or 23.5 ha $(0.5 \%)$ every year on average.

\section{Acknowledgment}

We would like to thank the anonymous reviewers and colleagues at Faculty of Forestry Universitas Sumatera Utara who has provided constructive and valuable advices in this article.

\section{REFERENCES}

[1] Rahmawaty, M M Harahap, H Kurniawan, and D Mandasari. "DPSIR model approach to address land-use changes in Deli Serdang District, North Sumatera Province," IOP Conf. Series: Earth and Environmental Science no. 724, p 012028. 2021.

[2] Rahmawaty, M M Harahap, H Kurniawan, and A Rauf. "Assessment of land cover change over a period of five years in Deli Serdang, North Sumatra," IOP Conf. Series: Earth and Environmental Science no. 782, p 032007. 2021.

[3] Khairunnisa, E. S. dan P. N. Indradjati. "Evaluasi Fungsi Ekologis Ruang Terbuka Hijau di Kota Bandung Dalam Upaya Pengendalian Iklim Mikro Berupa Pemanasan Lokal dan Penyerapan Air (Studi Kasus: Taman Taman Di WP Cibeunying)," Jurnal Perencanaan Wilayah dan Kota vol. 2, pp. 1-10. 2011.

[4] Sitorus S. R. P, E. Mustamei, S. P. Mulya. "Keselarasan Penggunaan Lahan dengan Pola Ruang dan Arahan Pengembangan Ruang Terbuka Hijau di Kabupaten Bengkulu Selatan,” Jurnal Ilmu Tanah dan Lingkungan vol 21, no 1, pp. 21-29. 2019.

[5] Kementerian Pekerjaan Umum, Peraturan Menteri Pekerjaan Umum Nomor 05/PRT/M/2008 tentang Pedoman Penyediaan dan Pemanfaatan Ruang Terbuka Hijau di Kawasan Perkotaan, 2008.

[6] BPS, Surakarta dalam Angka 2013, Badan Pusat Statistik Kota Surakarta, Surakarta, 2014.

[7] Bappeda, Profil Daerah Surakarta 2011, Badan Perencanaan dan Pembangunan Daerah Surakarta, 2011.

[8] BPS, Surakarta dalam Angka 2016, Badan Pusat Statistik Kota Surakarta, Surakarta, 2017. 
[9] Putra, A. K., A. Sukmono dan B. Sasmito. "Analisis Hubungan Perubahan Tutupan Lahan terhadap Suhu Permukaan terkait Fenomena Urban Heat Island Menggunakan Citra Landsat (Studi Kasus: Kota Surakarta)," Jurnal Geodesi Undip vol 7, no 3, pp. 22-31. 2018.

[10] Samsuri, A Zaitunah and J. F Manurung. "Analysis of Forest Landscape Fragmentation in Samosir Island, North Sumatra," IOP Conf. Series: Earth and Environmental Science no. 166, p 012007. 2018.

[11] Lillesand T.M. and Kiefer R.W. Penginderaan Jauh dan Interpretasi Citra, Gadjah Mada University Press, Yogyakarta, 1990.

[12] Sukojo, B. M dan Susilowati, D. "Penerapan Metode Penginderaan Jauh dan Sistem Informasi Geografis untuk Analisa Perubahan Penggunaan Lahan (Studi Kasus: Wilayah Kali Surabaya)," Jurnal Makara Teknologi vol. 7, no 1, pp. 1-9. 2003.

[13] Tiwari, M. K., A. Saxena. "Change Detection of Land Use/Landcover Pattern in An Around Mandideep and Obedullaganj Area, using Remote Sensing and GIS," Int. J. Technol. Eng. Syst. vol. 2, no. 3, pp. 398-402. 2011.

[14] Republik Indonesia, Undang-Undang Nomor 26 Tahun 2007 tentang Penataan Ruang, 2007.

[15] Susilowati, A., Rangkuti, A. B., Rachmat, H. H., Iswanto, A. H., Harahap, M. M., Elfiati, D., Slamet, B. and Ginting, I. M. "Maintaining Tree Biodiversity in Urban Communities on The University Campus," Biodiversitas Journal of Biological Diversity, vol. 22, no. 5, pp. 2839-2847. 2021.

[16] Nugraheni, D. S., R. A. Putri dan E. F. Rini. "Kemampuan Tutupan Vegetasi RTH dalam Menyerap Emisi $\mathrm{CO}_{2}$ Sektor Transportasi di Kota Surakarta," Jurnal Pembangunan Wilayah dan Perencanaan Partisipatif vol. 13, no 2, pp. 182-198. 2018.

[17] Lakshita, N. M., D. Muharrama, M. Z. A. J. Ramadhan, M. F. Ahsani dan Y. Prihanto. "Identifikasi Perubahan Lahan Sawah Kota Surakarta Menggunakan Metode NDVI," SEMNAS Geomatika 2019: Geomatics Scientific Meeting on Coastal Management to Support SDG, 2019.

[18] USAID, Mengenal Sistem Perkotaan: Sebuah Pengantar Tentang Kota Solo. Surakarta, 2010.

[19] Zaitunah. A., Samsuri, Slamet. B. "Analysis of Greenbelt in Sibolga for Tsunami Mitigation," Earth and Environmental Science, IOP Publishing, no. 166, pp. 1-11. 2018.

[20] Zhang M, Wang K, Chen H. "Impacts of land use and land cover changes upon organic productivity values in Karst ecosystems: a case study of Northwest Guangxi, China Front," Earth Sci. China vol. 4, pp. 3-13. 2010 